\title{
DEVELOPING WOPIPOPU (WORDLESS PICTURE POP-UP) BOOK MEDIA ON SCIENTIFIC LEARNING AT GRADE 4 ELEMENTARY SCHOOL
}

\author{
Syopiani Oktavia ${ }^{1}$, Syachruroji $^{2}$, Nana Hendracipta ${ }^{3}$ \\ 1,2,3 PGSD, Universitas Sultan Ageng Tirtayasa, Indonesia \\ 'syopianio@gmail.com, 2ahmadsyachruroji@gmailuntirta.ac.id, ${ }^{3}$ nanahendracipta@untirta.ac.id
}

\section{PENGEMBANGAN MEDIA PEMBELAJARAN WOPIPOPU BOOK (WORDLESS PICTURE POP-UP BOOK) DALAM PEMBELAJARAN SAINTIFIK DI KELAS IV SD}

\begin{tabular}{|c|c|}
\hline ARTICLE HISTORY & ABSTRACT \\
\hline $\begin{array}{l}\text { Submitted: } \\
20 \text { Oktober } 2020 \\
20^{\text {nd }} \text { October } 2020\end{array}$ & $\begin{array}{l}\text { Abstract: This research aimed to develop scientific-based Wopipopu Book media as a means of } \\
\text { visual learning style for students at grade IV elementary school and to know the feasibility of } \\
\text { the Wopipopu Book media. This research was conducted at SD Negeri Kebon Jahe, } \\
\text { Kecamatan Serang, Serang, involving } 23 \text { students at grade IV in a limited trial. This research } \\
\text { and development used a model modified by Sugiyono. This model consists of } 6 \text { stages namely } \\
\text { problem analysis, data collection, product design, design validation, design revision, and } \\
\text { product trial. The instruments of this research were questionnaires for media validation by } \\
\text { lecturers and questionnaire for students. Based on the result of data analysis, it was concluded } \\
\text { that the quality of Wopipopu Book learning media was categorized as very feasible with a } \\
\text { percentage of } 92.8 \% \text { from } 2 \text { material experts, feasible with a percentage of } 75.8 \% \text { from } 2 \\
\text { linguists, and } 91.5 \% \text { from } 2 \text { media experts. Furthermore, the percentage of students response } \\
\text { to Wopipopu Book in the trial was } 84.64 \% \text { with excellent category. }\end{array}$ \\
\hline
\end{tabular}

Keywords: Learning Media, Saintific, Wordless Picture, Pop-Up

Accepted:

14 April 2021

$14^{\text {th }}$ April 2021

Published:

27 Juni 2021

$27^{\text {th }}$ June 2021

\begin{abstract}
Abstrak: Penelitian ini bertujuan untuk mengetahui cara mengembangkan media pembelajaran Wopipopu Book berbasis saintifik sebagai sarana gaya belajar visual peserta didik di kelas IV Sekolah Dasar dan untuk mengetahui kelayakan media pembelajaran Wopipopu Book dalam pembelajaran saintifik di kelas IV Sekolah Dasar yang dikembangkan mendapat penilaian yang layak dari pakar. Penelitian ini dilakukan di SD Negeri Kebon Jahe, Kecamatan Serang, Kota Serang, dengan subjek penelitian siswa kelas IV sejumlah 23 siswa pada uji coba terbatas. Jenis penelitian ini menggunakan model yang dimodifikasi oleh Sugiyono. Model ini terdiri dari 6 tahap yaitu analisis masalah, pengumpulan data, desain produk, validasi desain, revisi desain dan uji coba produk. Instrumen yang digunakan berupa lembar angket untuk validasi media oleh dosen serta lembar angket peserta didik. Berdasarkan analisis data, dapat disimpulkan bahwa kualitas media pembelajaran Wopipopu Book yang dikembangkan termasuk kategori sangat layak dengan persentase $92.8 \%$ dari 2 ahli materi, kategori layak dengan persentase $75.8 \%$ dari 2 ahli bahasa, dan $91.5 \%$ dari 2 ahli media. Respon siswa terhadap media pembelajaran Wopipopu Book pada uji coba dengan 23 responden sebesar $84.64 \%$ dengan kategori sangat baik.
\end{abstract}

Kata Kunci: Media Pembelajaran, Saintifik, Wordless Picture, Pop-Up

\section{CITATION}

Oktavia, S., Syachruroji, S., \& Hendracipta, N. (2021). Developing Wopipopu (Wordless Picture Pop-Up) Book Media on Scientific Learning at Grade 4 Elementary School. Primary: Jurnal Pendidikan Guru Sekolah Dasar, 10 (3), 669-679. DOI: http://dx.doi.org/10.33578/jpfkip.v10i3.8142. 


\section{PENDAHULUAN}

Keterampilan menulis merupakan suatu kemampuan dimana seseorang mampu menuangkan ide atau gasasan dalam sebuah tulisan. Menurut Rosyidah, dkk. (2013) kemampuan menulis merupakan salah satu keterampilan berbahasa yang harus diajarkan pada siswa. keterampilan menulis mempunyai peranan yang sangat penting dalam kehidupan sehari-hari. Cere dalam Yarmi G. (2017) menyatakan bahwa menulis merupakan salah satu bentuk komunikasi. Selanjutnya dikatakan bahwa di dalam komunikasi terdapat empat unsur, yaitu (1) menulis merupakan bentuk ekspresi diri; (2) menulis merupakan sesuatu yang umum disampaikan kepada pembaca; (3) menulis merupakan aturan dan tingkah laku; dan (4) menulis merupakan sebuah cara belajar. Sebagai bentuk dari ekspresi diri, menulis bertujuan untuk mengkomunikasikan, menyampaikan sebuah ide melewati batas waktu ruang. Artinya, menulis dapat dilakukan kapan saja, dan di mana saja sesuai dengan keadaan yang terdapat dalam diri penulis. Keterampilan menulis juga merupakan syarat berkecimpung dalam berbagai bidang atau kegiatan. Hal ini memperlihatkan bahwa betapa pentingnya keterampilan dan kemampuan menulis dalam kehidupan seharihari.

Menurut Rosyidah, dkk. (2013) pendekatan adalah konsep dasar yang mewadahi, menginspirasi, menguatkan, dan melatari metode pembelajaran dengan cakupan teoritis tertentu. Hal ini sejalan dengan pendapat dari Kemendikbud (2016) tentang Materi Pelatihan Implementasi Kurikulum 2013 yang mengatakan bahwa pendekatan pembelajaran adalah suatu rangkaian tindakan pembelajaran yang dilandasi oleh prinsip dasar tertentu (filosifis, psikologis, didaktis, dan ekologis) yang mewadahi, menginspirasi, menguatkan dan melatari metode pembelajaran tertentu. Menurut Aprison W. \& Junaidi (2017) mengatakan bahwa pendekatan saintifik dalam Kurikulum 2013 pertama muncul dalam Peraturan Menteri Pendidikan dan Kebudayaan
Nomor 65 Tahun 2013 tentang Standar Proses Pendidikan Dasar dan Menengah. Karakteristik kompetensi beserta perbedaan lintasan perolehan turut serta mempengaruhi karakteristik standar proses. Ditinjau dari klasifikasi pendekatan, pendekatan saintifik termasuk ke dalam student centered approach karena dalam prosesnya lebih mengutamakan peserta didik yang aktif dalam proses pembelajaran dan guru berperan sebagai fasilitator. Dari sudut tinjauan proses, pendekatan saintifik merupakan pendekatan pembelajaran yang berorientasi pada langkahlangkah kerja ilmiah (Rostika D. \& Prihartini, 2019). Daryanto (2014) juga mengatakan bahwa pendekatan saintifik adalah proses pembelajaran yang dirancang sedemikian rupa agar siswa secara aktif mengkonstruksi konsep, hukum, atau prinsip melalui tahapantahapan mengamati, merumuskan masalah, mengajukan atau merumuskan hipotesis, mengumpulkan data dengan berbagai teknik, menganalisis data, menarik kesimpulan dan mengkomunikasikan konsep, hukum atau prinsip yang ditemukan.

Langkah-langkah pendekatan ilmiah (scientific approach) dalam proses pembelajaran pada Kurikulum 2013 untuk semua jenjang dilaksanakan dengan menggunakan pendekatan ilmiah (saintifik), meliputi: menggali informasi melalui observing/pengamatan, questioning/bertanya, experimenting/percobaan, kemudian mengolah data, menyajikan data, dilanjutkan dengan menganalisis, associating/menalar, kemudian menyimpulkan, dan mencipta dan serta membentuk jaringan/networking. Menurut Hosnan M. (2016) menyatakan bahwa aktivitas guru dalam kegiatan pembelajaran saintifik adalah: 1) menyediakan sumber belajar; 2) mendorong siswa berinteraksi dengan sumber belajar (menugaskan); 3) mengajukan pertanyaan agar siswa memikirkan hasil interaksinya; 4) memantau persepsi dan proses berpikir siswa serta memberikan scaffolding; 5) mendorong siswa berdialog/berbagi hasil pemikirannya; 6) mengkonfirmasi pemahaman 
yang diperoleh; dan 7) mendorong siswa untuk merefleksikan pengalaman belajarnya.

Siswa SD berkaitan dengan hal-hal yang abstrak, maka dari itu membutuhkan media yang nyata/konkret. Media ini dibuat dengan menggunakan pendekatan saintifik yang di dalamnya meliputi kegiatan mengamati, kegiatan menanya, kegiatan mengumpulkan informasi, kegiatan mengasosiasikan/mengolah informasi, dan kegiatan mengomunikasikan.

Pada penelitian ini, peneliti akan mengembangkan media pembelajaran buku cetak yakni Wopipopu Book yang mana merupakan penggabungan antara Wordless Picture Book dan Pop-up Book. Dengan media ini, siswa bisa memperoleh gambaran yang konkret atas suatu peristiwa atau kejadian sehingga memudahkan siswa untuk memahaminya. Siswa akan merasa seolah-olah bahwa ia sedang berada dalam situasi yang ada pada cerita di dalam media ini melalui gambargambar. Hal ini membuat siswa tidak hanya belajar untuk menulis sebuah cerita tetapi berdasarkan kesimpulan yang ia buat setelah melihat gambar tetapi juga berimajinasi tanpa batas.Oleh karena itu, peneliti memfokuskan pada pengembangan media pembelajaran Wopipopu Book pada Tema 4, Subtema 1, Pembelajaran 1 di SD Negeri Kebon Jahe, Kecamatan Serang, Kota Serang, Prov. Banten, Indonesia.

\section{METODE PENELITIAN}

Metode penelitian yang digunakan adalah metode penelitian pengembangan (Research and Development), merupakan metode penelitian yang digunakan untuk menghasilkan dan menguji keefektifan produk tertentu. Menurut Sugiyono (2010) untuk dapat menghasilkan produk tertentu digunakan penelitian yang bersifat analisis kebutuhan dan untuk menguji keefektifan produk tersebut supaya dapat berfungsi dimasyarakat luas, maka diperlukan penelitian untuk menguji keefektifan produk tersebut.

Penelitian ini merujuk pada metode pengembangan menurut Borg and Gall dalam Sugiyono (2016) yang telah dimodifikasi meliputi 6 langkah yaitu analisis masalah, pengumpulan data, desain produk, validasi desain, revisi desain, dan uji coba produk terbatas.

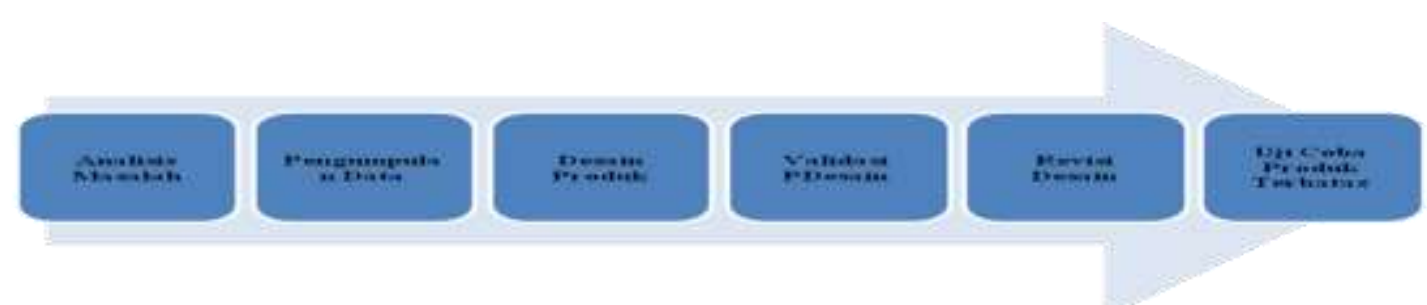

Gambar 1. Modifikasi Alur Penelitian RnD Sugiyono (2016)

Adapun langkah-langkah penelitian secara terperinci dapat dilihat pada gambar $1 \mathrm{di}$ bawah ini: 


\section{PRIMARY: JURNAL PENDIDIKAN GURU SEKOLAH DASAR \\ VOLUME 10 NOMOR 3 JUNI 2021 \\ ISSN : 2303-1514 | E-ISSN : 2598-5949 \\ DOI : http://dx.doi.org/10.33578/jpfkip.v10i3.8142 https://primary.ejournal.unri.ac.id/index.php/JPFKIP}

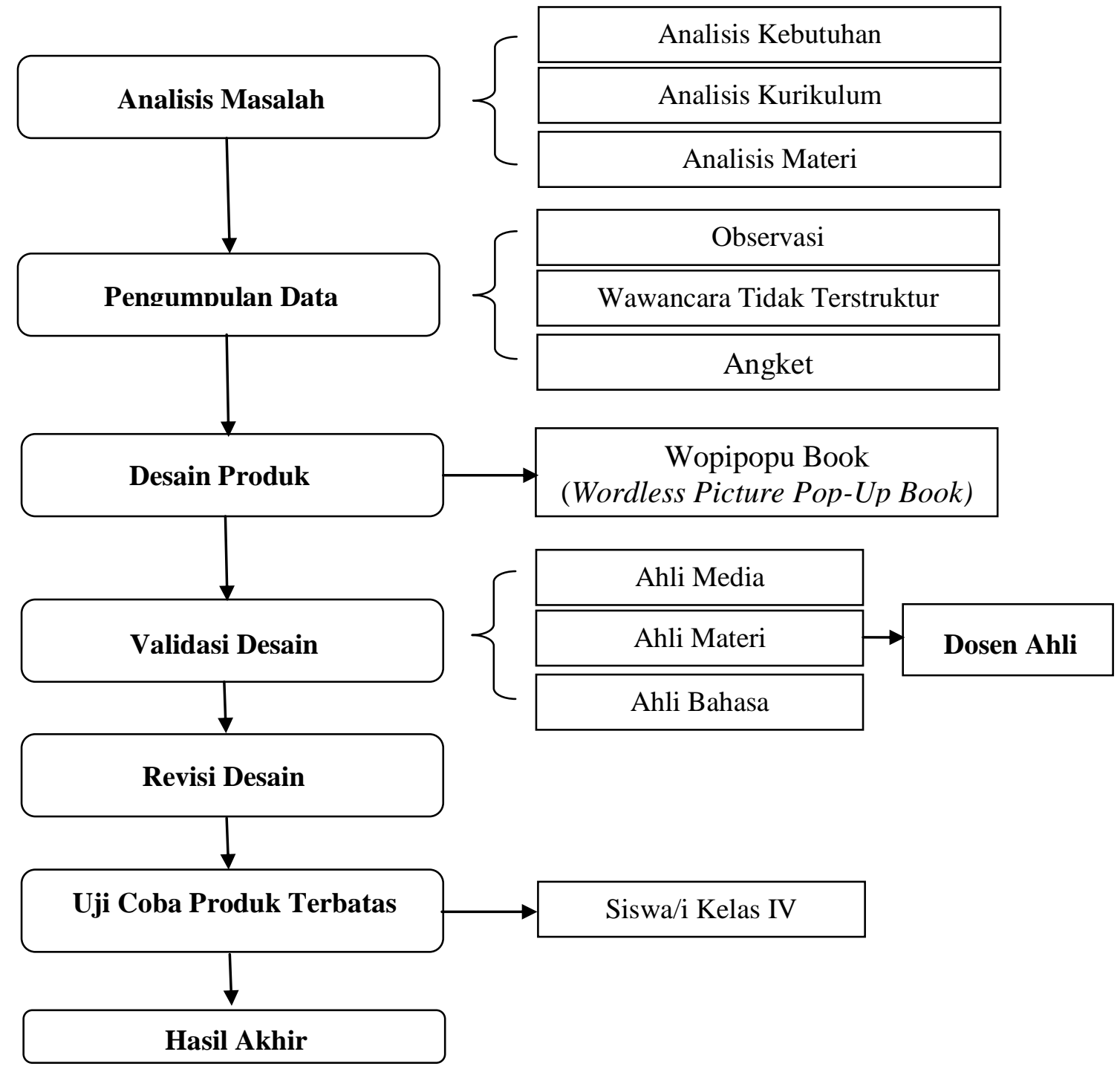

Gambar 2. Langkah-Langkah Desain Penelitian RnD Sugiyono (2016)

Gambar di atas menjelaskan mengenai langkah-langkah penelitian menggunakan desain dari Sugiyono yang mana terdapat 6 tahap penelitian mulai dari analisis masalah, pengumpulan data, desain produk, validasi desain, revisi desain, dan uji coba produk terbatas dengan diakhiri hasil dari respon siswa terhadap media pembelajarn Wopipopu Book dalam pembelajaran saintifik di kelas IV SD.

Sumber data yang dugunakan berupa hasil wawancara tidak terstruktur, observasi, dokumentasi dari analisis masalah yang terdiri dari analisis kebutuhan, analisis kurikulum, dan analisis materi pada Tema 4 Subtema 1 Jenis-Jenis Pekerjaan. Selain itu, dilakukan juga validasi dari tim ahli materi, ahli bahasa, dan ahli media serta respon siswa yang mana komentar serta saran dari ahli digunakan sebagai pertimbangan dalam melakukan revisi media pembelajaran. Sedangkan untuk data kuantitatif berupa skor penilaian yang diberikan oleh tim ahli dan respon siswa yang nantinya akan dianalisis sesuai kriteria yang telah ditentukan sehingga dapat diketahui 
kelayakan dari media itu sendiri.

Teknik analisis data untuk uji ahli dan respon siswa dilakukan berdasarkan data masukan berupa lembar penilaian menggunakan skala likert dengan skor 1, 2, 3, 4, dan 5 dengan menggunakan rumus-rumus di bawah ini:

$$
\mathrm{NP}=\frac{R}{S M} \times 100 \%
$$

Keterangan:

NP : Nilai rata-rata dalam (\%)

$\mathrm{R} \quad$ : Skor yang diperoleh dari setiap aspek.

SM : Skor maksimum dari seluruh aspek.

100 : Bilangan tetap.

Kriteria interpretasi skor persentase yang didapatkan dari uji kelayakan penilaian ahli pada table berikut:

Tabel 1. Kategori Kelayakan Media

\begin{tabular}{lc}
\hline \multicolumn{1}{c}{ Skor dalam Persen (\%) } & Kategori Kelayakan \\
\hline$<20 \%$ & Tidak Layak \\
\hline $21 \%-40 \%$ & Kurang Layak \\
\hline $41 \%-60 \%$ & Cukup Layak \\
\hline $61 \%-80 \%$ & Layak \\
\hline $81 \%-100 \%$ & Sangat Layak \\
\hline & [Arikunto, 2006]
\end{tabular}

Mendeskripsikan hasil angket siswa terhadap ketertarikan pada media Wopipopu Book berbasis pembelajaran saintifik yang dibuat oleh peneliti, maka dihitung dengan rumus berikut:

$$
N P=\frac{n}{N} \times 100 \%
$$

\section{Keterangan:}

NP : Persentase sikap siswa setiap indikator.

n : Jumlah skor siswa untuk setiap indikator.

$\mathrm{N}$ : Jumlah skor total untuk setiap indikator.

Selanjutnya mencari nilai rata-rata dari seluruh indikator, dengan menggunakan rumus:

$$
\tilde{x}=\frac{\sum x_{1}}{n} \times 100 \%
$$

\section{Keterangan:}

$\tilde{\bar{x}} \quad$ : Nilai rata-rata.

$\sum x_{1}$ : Jumlah seluruh nilai data.

$\mathrm{n} \quad$ : Jumlah indikator.

Hasil penilaian yang diperoleh diinterpretasikan berdasarkan table di bawah ini:

Tabel 2. Kriteria Interpretasi Respon Siswa

\begin{tabular}{cc}
\hline Skor dalam Persen (\%) & Kategori Kelayakan \\
\hline $81 \%-100 \%$ & Sangat Baik \\
\hline $61 \%-80 \%$ & Baik \\
\hline $41 \%-60 \%$ & Cukup \\
\hline $21 \%-40 \%$ & Kurang \\
\hline$<20 \%$ & Sangat Kurang
\end{tabular}

\section{HASIL DAN PEMBAHASAN}

Penelitian pengembangan ini menghasilkan produk berupa buku cetak sebagai media pembelajaran saintifik di kelas IV SD Negeri Kebon Jahe, Kecamatan Serang, Kota Serang, Banten yang layak digunakan.
[Riduwan, 2013]

Hal tersebut dapat dilihat dari hasil validasi kelayakan yang diberikan oleh validator serta hasil dari uji coba terbatas untuk melihat respon siswa terhadap produk yang peneliti kembangkan berdasarkan tahapan penelitian $\mathrm{RnD}$ yang meliputi tahap analisis masalah, 
pengumpulan data, desain produk, validasi desain, revisi desain dan uji coba produk terbatas. Berikut secara lebih rinci mengenai tahapan penelitian $\mathrm{RnD}$ yang dilakukan oleh peneliti.

\section{Tahap Analisis Masalah}

Pada tahapan ini dilakukan analisis kebutuhan di sekolah, analisis kurikulum, dan analisis materi. Tahap analisis masalah dalam penelitian ini secara lebih rinci dapat pada penjelasan di bawah ini:

\section{Analisis Kebutuhan}

Tahap ini bertujuan untuk mengetahui sekiranya apa yang dibutuhkan untuk mengatasi masalah yang ada di SD Negeri Kebon Jahe Kecamatan Serang, Kota Serang khususnya di kelas IV. peneliti melakukan wawancara tidak terstruktur bersama wali kelas untuk menanyakan seputar keadaan di kelas IV tersebut kemudian peneliti bandingkan dengan hasil observasi ketika di kelas. Sehingga didapatkan informasi bahwa di kelas IV sebagian besar siswa belum lancar membaca, di sekolah tersebut juga tidak pernah menggunakan jenis pendekatan lainnya selain pendekatan tematik dalam pembelajaran di kelas, dan siswa kurang aktif ketika di kelas karena tidak ada yang mampu memotivasi siswa dalam belajar misalnya dengan menggunakan media pembelajaran.

Maka dari itu, media pembelajaran Wopipopu Book berbasis pembelajaran saintifik sangat dibutuhkan dengan harapan media yang dikembangkan oleh peneliti ini dapat memotivasi siswa dalam belajar sekaligus mampu membangkitkan partisipasi aktif siswa dengan menerapkan pembelajaran saintifik dalam pembelajaran menulis tanpa menghilangkan keterampilan proses yang harus ada pada pembelajaran saintifik di kelas.

\section{Analisis Kurikulum}

Tahap berikutnya merupakan lanjutan dari tahap analisis kebutuhan. Analisis kurikulum ini bertujuan agar isi materi pada media pembelajaran Wopipopu Book sesuai dengan kurikulum yang digunakan di sekolah.

\section{Analisis Materi}

Analisis materi ini merupakan tahap lanjutan dari analisis kebutuhan dan analisis kurikulum. Pada tahap ini seperti pada Lampiran A.3 Analisis Materi, peneliti membuat peta materi yang mana dari peta materi tersebut ditentukanlah materi yang akan digunakan yakni Tema 4 Subtema 1 Pembelajaran ke-1.

\section{Tahap Pengumpulan Data}

Data yang dihasilkan pada tahap ini berupa wawancara dan dokumentasi dari analisis masalah yang terdiri dari analisis kebutuhan, analisis kurikulum, dan analisis materi pada Tema 4 Subtema 1 Jenis-Jenis Pekerjaan.

\section{Tahap Desain Produk}

Tahap desain produk ini dilakukan dengan membuat draft awal (storyboard). Langkah yang pertama, yaitu peneliti menyiapkan materi yang telah disesuaikan pada tahap desain. Kemudian disusun berdasarkan urutan tahapan dalam pembelajaran saintifik yang disesuaikan dengan kurikulum yang dipakai di SD Negeri Kebon Jahe.

Langkah selanjutnya adalah peneliti mencari gambar slide animasi yang menceritakan Legenda Batu Kuwung di youtube beserta gambar-gambar pendukung lainnya di google dengan format png yang akan digunakan di dalam Wopipopu Book. Ketika menemukan gambar slide animasi yang akan digunakan sebagai dasar buku, peneliti meminta izin kepada pihak pengunggah video animasi tersebut melalui media sosial. Setelah mendapat izin yang nantinya sumber pemilik gambar animasi lengkap dengan alamat situsnya akan dicantumkan pada laman Daftar Pustaka pada Wopipopu Book, peneliti mulai memilah dan memilih sekiranya bagian mana dari gambar slide animasi tersebut yang akan digunakan.

Setelah berbagai macam gambar yang dibutuhkan telah tersedia, peneliti mulai 
menata gambar-gambar tersebut dan mulai pada tahap editing melalui aplikasi Microsoft Powerpoint mulai dari halaman judul hingga halaman terakhir semua diedit menggunakan aplikasi ini. Alasan peneliti menggunakan aplikasi ini yaitu karena aplikasi Microsoft Powerpoint memiliki banyak jenis font dan warna-warna yang menarik. Selain itu, aplikasi ini mudah digunakan bagi peneliti serta tidak mengeluarkan banyak biaya.

Tahap berikutnya yakni proses cetak buku. Gambar-gambar yang telah diedit kemudian dicetak dengan ukuran A3+ dengan menggunakan kertas art papper dan beberapa bagian dibuat glossy, tujuannya ketika peserta didik melakukan kegiatan tempel-menempel di dalam Wopipopu Book, kertas tidak mudah rusak. Setelah semua dicetak, peneliti mulai menggabungkan setiap lembar sehingga menjadi buku besar. Untuk bagian pop-up, peneliti membuatnya secara manual atau digambar. Bagian pop-up ini dilakukan pada saat kertas telah ditempel dan disatukan menyerupai buku paket dengan ukuran besar.

Tahap akhir adalah pembuatan hard cover. Pada tahap ini, buku yang telah jadi diukur dan dibuat hardcover dari bahan kardus dan juga kertas art papper. Peniliti melakukan tahap ini secara individual, artinya tanpa bantuan pihak lain seperti percetakan. Pada hard cover tersebut, peneliti membuat gambar secara manual menggunakan tangan untuk covernya baik pada bagian depan maupun belakang. Setelah itu, peneliti melapisi cover buku menggunakan plastik sampul agar buku sedikit lebih tahan lama.

Berikut ini contoh proses desain awal dari Wopipopu Book sebelum dilakukan tahap validasi produk:

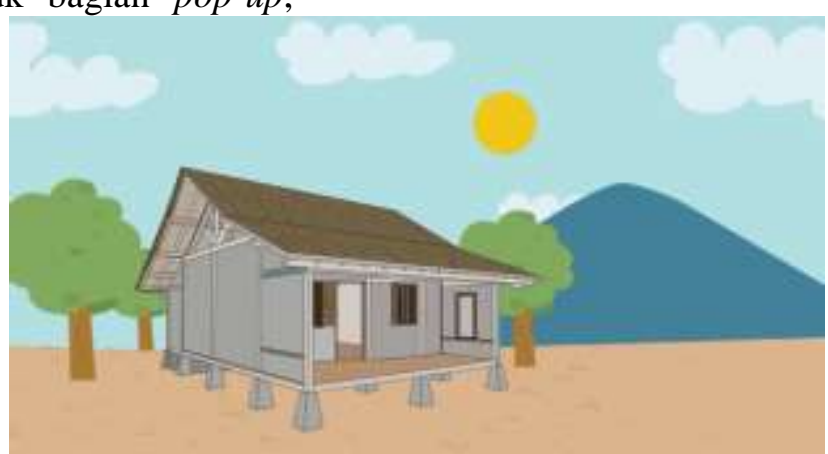

Gambar 3. Gambar Slide Animasi "Legenda Batu Kuwung" Sumber : Dwika Apriyani, 2018 (https://youtu.be/0wrhRRK4zAs)

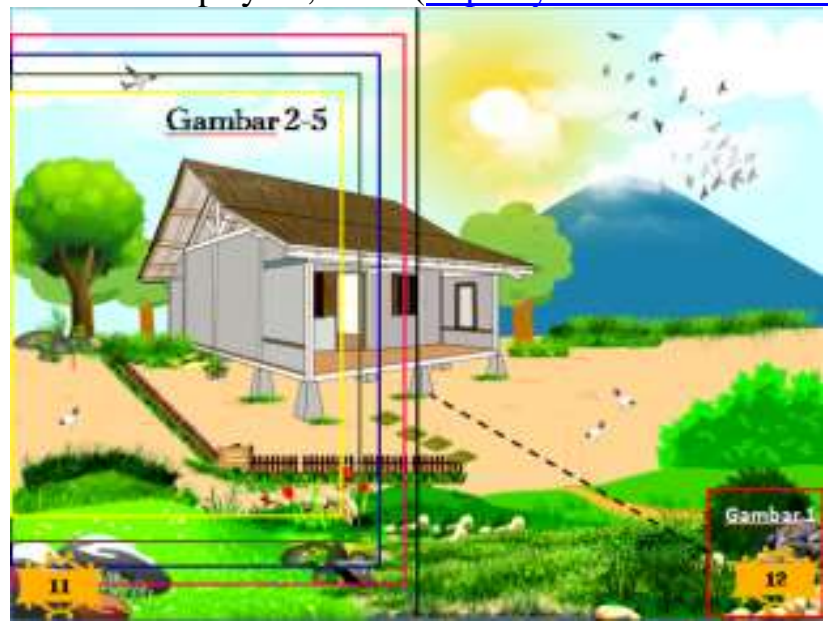

Gambar 4. Gambar Slide Animasi yang Telah Melalui Tahap Editing 


\section{PRIMARY: JURNAL PENDIDIKAN GURU SEKOLAH DASAR \\ VOLUME 10 NOMOR 3 JUNI 2021 \\ ISSN : 2303-1514 | E-ISSN : 2598-5949 \\ DOI : http://dx.doi.org/10.33578/jpfkip.v10i3.8142 \\ https://primary.ejournal.unri.ac.id/index.php/JPFKIP}

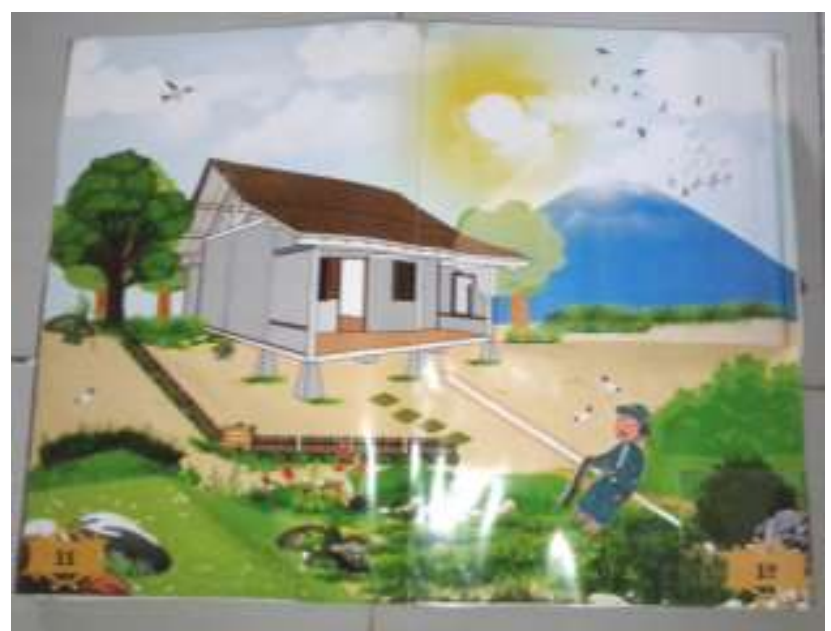

Gambar 5. Gambar Slide yang Telah Dicetak

\section{Tahap Validasi Desain}

Validasi dilakukan terhadap produk awal yang digunakan guna memperbaiki kekurangan agar pengembangan Wopipopu Book yang dihasilkan layak dipakai pada pembelajaran. Validasi dilakukan oleh 6 orang dosen dengan masing-masing 2 dosen untuk setiap ahli. Berdasarkan hasil validasi oleh para ahli, maka dapat disimpulkan bahwa Wopipopu Book yang telah dibuat peneliti sudah layak diujicobakan ke sekolah dengan perbaikan sesuai saran. Hasil dari validasi secara lebih rinci dapat dilihat di bawah ini:

\section{Validasi Ahli Materi}

Tabel 3. Hasil Validasi Ahli Materi

\begin{tabular}{cccc}
\hline Validator & Skor & Persentase $(\%)$ & Keterangan \\
\hline I & 82 & 91.1 & Sangat Layak \\
II & 85 & 94.4 & Sangat Layak \\
\hline
\end{tabular}

Berdasarkan tabel di atas, maka diperoleh jumlah skor dari Validator I sebesar 82 dari jumlah skor maksimal 90 dengan persentase sebesar $91.1 \%$ termasuk pada kriteria "Sangat Layak" dan jumlah skor dari Validator II sebesar 85 dari jumlah skor maksimal 90 dengan persentase sebesar $94,4 \%$ maka

termasuk pada kriteria "Sangat Layak". Berdasarkan hasil penilaian dari masingmasing ahli di dapat bahwa rata-rata persentasenya sebesar $92.8 \%$ yang masuk ke dalam kategori "Sangat Layak".

\section{Validasi Ahli Bahasa}

Tabel 4. Hasil Validasi Ahli Bahasa

\begin{tabular}{cccc}
\hline Validator & Skor & Persentase (\%) & Keterangan \\
\hline I & 47 & 78.3 & Layak \\
II & 44 & 73.3 & Layak \\
\hline
\end{tabular}

Berdasarkan tabel di atas, maka diperoleh jumlah skor dari Validator I sebesar 47 dari jumlah skor maksimal 60 dengan persentase sebesar $78.3 \%$ termasuk pada kriteria "Layak" dan jumlah skor dari Validator II sebesar 44 dari jumlah skor maksimal 60 dengan persentase sebesar $73.3 \%$ maka termasuk pada kriteria "Layak". 
Berdasarkan hasil penilaian dari masingmasing ahli di dapat bahwa rata-rata persentasenya sebesar $75.8 \%$ yang masuk ke dalam kategori "Layak".

\section{Validasi Ahli Media}

Tabel 5. Hasil Validasi Ahli Media

\begin{tabular}{cccc}
\hline Validator & Skor & Persentase $\mathbf{( \% )}$ & Keterangan \\
\hline I & 93 & 93 & Sangat Layak \\
II & 88 & 88 & Sangat Layak \\
\hline
\end{tabular}

Berdasarkan tabel di atas, maka diperoleh jumlah skor dari Validator I sebesar 93 dari jumlah skor maksimal 100 dengan persentase sebesar $95 \%$ termasuk pada kriteria“Sangat Layak"dan jumlah skor dari Validator II sebesar 88 dari jumlah skor maksimal 100 dengan persentase sebesar 88\% maka termasuk pada kriteria "Sangat Layak". Berdasarkan hasil penilaian dari masingmasing ahli di dapat bahwa rata-rata persentasenya sebesar $91.5 \%$ yang masuk ke dalam kategori "Sangat Layak".

Tabel 6. Komentar dan Saran Validator

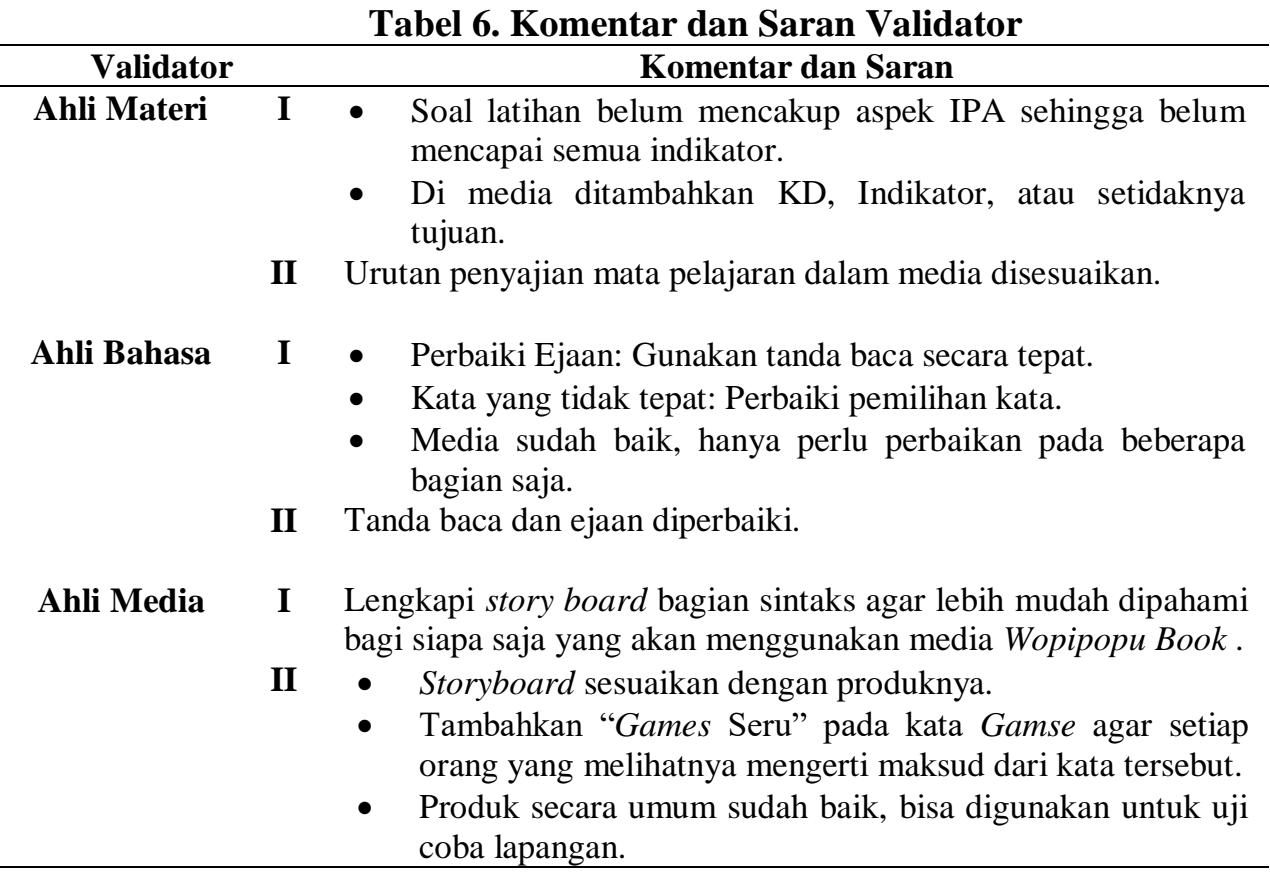

Tahap Uji Coba Produk Terbatas

Penelitian dilaksanakan di Kelas IV SD Negeri Kebon Jahe, Sekacamatn Serang, Kota Serang, Banten pada tahun ajaran

\section{Tahap Revisi Desain}

Setelah media Wopipopu Book ini divalidasi oleh ahli (materi, bahasa, dan media), dan ada beberapa masukan yang diinformasikan oleh para ahli guna menyempurnakan pengembangan media Wopipopu Book ini, sehingga media Wopipopu Book ini perlu adanya perbaikan sebelum dilakukan uji coba di sekolah. Berikut ini rincian mengenai komentar dan saranr dari masing-masing validator ahli:

2020/2021 dengan teknik luring namun tetap mematuhi protokol kesehatan dari pemerintah, yaitu dengan melakukan tahap belajar berkelompok yang mana perharinya hanya 
diisi oleh setengah dari jumlah siswa yang ada. Kegiatan dilaksanakan pada tanggal 19 dan 23 November 2020. Kemudian setelah berakhirnya kegiatan belajar mengajar, peserta didik diberikan angket respon terkait media Wopipopu Book yang telah diujicobakan. Berikut merupakan hasil respon peserta didik:

Tabel 7. Hasil Respon Siswa

\begin{tabular}{lccccc}
\hline No. & Aspek Penilaian & Jumlah Butir & $\begin{array}{c}\text { Jumlah Skor yang } \\
\text { Diperoleh }\end{array}$ & $\begin{array}{c}\text { Jumlah Skor } \\
\text { Maksimal }\end{array}$ & Persentase \\
\hline 1. Tampilan & 3 & 317 & 345 & $91.88 \%$ \\
2. Materi & 5 & 466 & 575 & $81.04 \%$ \\
3. Kemanfaatan & 4 & 385 & 460 & $83.70 \%$ \\
Jumlah & 12 & 1168 & 1380 & $256.62 \%$ \\
Rata-rata & & & $84.64 \%$ & \\
Kriteria Kelayakan & & & Sangat Baik & \\
\hline
\end{tabular}

\section{SIMPULAN DAN REKOMENDASI}

Penelitian yang dilakukan merupakan penelitian pengembangan Research and Development (R\&D) dengan tahapan pengembangan Borg and Gall yang telah dimodifikasi oleh Sugiyono. Hasil penelitian ini berupa media pembelajaran Wopipopu Book berbasis pembelajaran saintifik yang menunjukan bahwa:

1. Hasil validasi oleh ahli seluruhnya masuk kedalam kategori sangat layak dengan nilai rata-rata $86.68 \%$. Adapun rinciannya sebagai berikut:

a. Hasil validasi oleh ahli materi termasuk kedalam kategori sangat layak dengan nilai rata-rata $92.8 \%$.

b. Hasil validasi oleh ahli bahasa termasuk kedalam kategori layak dengan nilai rata-rata $75.8 \%$.

c. Hasil validasi oleh ahli media termasuk kedalam kategori sangat layak dengan nilai rata-rata $91.5 \%$.

2. Hasil angket respon siswa pada uji coba lapangan menunjukan nilai rata-rata $84.64 \%$ dengan kategori sangat baik.

Berdasarkan hasil tersebut, produk akhir berupa media pembelajaran buku cetak Wopipopu Book yang berbasis pembelajaran saintifik yang dihasilkan layak digunakan untuk kegiatan belajar peserta didi di kelas IV SD. Wopipopu Book yang dikembangkan dapat dijadikan alternatif media pembelajaran. Kepada peneliti selanjutnya diharapkan dapat mengembangkan media pembelajaran ini dengan menambahkan spesifikasi pendukung materi ajar yang akan diajarkan dan karakteristk peserta didik.Kesimpulannya harus bisa menjawab pertanyaan penelitian. Beberapa saran yang terkait dengan hasil dapat ditambahkan. Simpulan dan rekomendasi ini berisi kesimpulan dari hasil penelitian yang dilaksanakan.

\section{DAFTAR PUSTAKA}

Aprison, W. dan Junaidi. (2017). Pendekatan Saintifik: Melihat Arah Pembangunan Karakter dan Peradaban Bangsa Indonesia. Bukittinggi: Episteme, Jurnal Pengembangan Ilmu Keislaman, vol. 12, no. 2.

Arikunto, S. (2006). Penelitian Suatu Pendekatan Praktik. Jakarta: PT. Rineka Cipta.

Daryanto, H. (2013). Pendekatan Pembelajaran Saintifik Kurikulum 2013. Yogyakarta: Gava Media.

Hosnan, M. (2016). Pendekatan Saintifik dan Kontekstual dalam Pembelajaran Abad 21. Bogor: Ghalia Indonesia.

Kemendikbud. (2016). Materi Pelatihan Implementasi Kurikulum 2013. Jakarta: Kemendikbud.

Riduwan. (2013). Belajar Mudah Penelitian untuk Guru, Karyawan, dan Peneliti Pemula. Bandung: Alfabeta. 


\section{PRIMARY: JURNAL PENDIDIKAN GURU SEKOLAH DASAR \\ VOLUME 10 NOMOR 3 JUNI 2021 \\ ISSN : 2303-1514 | E-ISSN : 2598-5949 \\ DOI : http://dx.doi.org/10.33578/jpfkip.v10i3.8142 \\ https://primary.ejournal.unri.ac.id/index.php/JPFKIP}

Rostika, D., dan Prihartini. (2019).

Pemahaman Guru tentang Pendekatan

Saintifik dan Implikasinya dalam

Penerapan Pembelajaran di Sekolah

Dasar. Eduhumaniora : Jurnal

Pendidikan Dasar, vol. 11, no. 1, hal. 86-94.

Rosyidah, S. R., dan Ermanto. (2013). Peningkatan Keterampilan Menulis

Cerita melalui Teknik Tiru Model

Siswa Kelas III SD Negeri 200208

Padangsidimpuan. Universitas Negeri

Padang: Jurnal Bahasa, Sastra, dan Pembelajaran, vol. 1, no. 3.

Sugiyono. (2010). Metode Penelitian

Pendidikan: Pendekatan Kuantitatif,

Kualitatif, dan $R \& D$. Bandung:

Alfabeta.

Sugiyono. (2016). Metode Penelitian

Pendidikan: Pendekatan Kuantitatif,

Kualitatif, dan $R \& D$. Bandung:

Alfabeta.

Yarmi, G. (2017). Pembelajaran Menulis di Sekolah Dasar. UNJ: Perspektif. 